\title{
Re-reading the Never-Never
}

\author{
Chris O'Brien
}

You've probably never thought of the Northern Territory as a republic of letters. For most of my life I didn't either. Other, often conflicting, associations abound for this remarkable place: adventure, danger, spirituality, Aboriginal people and culture, desert, rainforest, heat, monsoons, crocodiles, cyclones, emptiness ... synecdoche NT. Some of these even lured me there. Then I stayed a while. And I saw books on the shelves of Darwin bookshops that I had never seen elsewhere. Then I read Mickey Dewar's In Search of the Never-Never.

Unfortunately this reissue has a sad genesis. Mickey Dewar died prematurely in April 2017. Mickey bequeaths a rich body of work about a part of Australia we should all know more about. To honour Mickey's substantial contributions to the discipline of history the Australian Historical Association (AHA) and Professor Ann McGrath of The Australian National University, a decades-long friend and colleague to Mickey, organised a special session at the 2017 AHA conference. Extended the privilege to speak about Mickey's scholarly legacy, I took the opportunity to reflect on In Search of the Never-Never. This essay is an expansion of that paper. It is a meditative re-reading of a grossly underrated work of cultural history. My aim here is to persuade you of its significance and, frankly, to entice you read the book, carefully.

The Northern Territory, its communities and distinctive locales have been the subject of some great historical scholarship. Perhaps the best known relate to war history and the bombing of Darwin during the Second World War. But a vast corpus focused on other topics coexists with these. Alan Powell's best known works Far Country (1982) and Northern Voyagers (2010) are expansive histories of the Territory in its larger physical and geographical contexts. David Carment has written extensively on 
the material history, cultural history, built environment and politics of particular Territory settlements, as well as of the Territory as a whole. ${ }^{1}$ Ann McGrath, Peter Read and Tim Rowse have written about NT Indigenous histories and place in the NT. ${ }^{2}$ Detailing the sojourns of the Macassans, Campbell Macknight showed that the region has long been connected to Asia. ${ }^{3}$ More recently, Deborah Bird Rose and Darrell Lewis have produced important Indigenous and environmental histories. ${ }^{4}$ Regina Ganter has elucidated the intricacies of race relations in polyglot Darwin. ${ }^{5}$ Henry Reynolds placed them in an even broader, northern Australian context. ${ }^{6}$ Most recently, NT histories have investigated Aboriginal public servants, cultural contact between Aboriginal communities and Christian missionaries, sport, culture and race, architecture, even weather and climate. ${ }^{7}$ Many more deserve mention but space restrictions forbid. Even among such a rich textual mosaic, Mickey Dewar's works stand out. They include The 'Black War' in Arnhem Land (1992) and Darwin - No Place Like Home (2010), which cover crucial aspects of Indigenous, political and cultural history in the Territory. But In Search of the Never-Never stands apart even from them.

Initially published in 1997, Never-Never is a cultural history unlike any other published about the Territory. As an environmental historian, I am interested in what US environmental historian William Cronon called 'stories about stories about nature'. ${ }^{8}$ Never-Never reflects on stories about stories about the Northern Territory. Its scope is breathtaking: the body of surviving book-length and long-form fiction and non-fiction published about any part of the NT from the mid-nineteenth century to the 1990s. Ordering this ocean of words into currents of thought is an achievement in itself. Mickey Dewar is explicit about her method: identify the repeated use of recognisable images. Trace the origins of these images, then the history of their use, noting changes in meaning over time. ${ }^{9}$ We get to see the life

1 Two of many examples include Territorianism: Politics and Identity in Australia's Northern Territory 1978-2001 and Looking at Darwin's Past.

2 Examples include, McGrath, 'Born in the Cattle'; Read, Long Time, Olden Time; Rowse, Indigenous and Other Australians since 1901.

3 Macknight, The Voyage to Marege.

4 Rose, Reports from a Wild Country; Lewis, A Wild History.

5 Ganter, Mixed Relations.

6 Reynolds, North of Capricorn.

7 Examples include Ganter, Reluctant Representatives; Rademaker, Found in Translation; O'Brien,

'Rethinking Seasons'.

8 Cronon, 'A Place for Stories', 1375.

9 Dewar, In Search of the Never-Never, xi. 
of prevailing attitudes and representations of land, wilderness, Aboriginal people, women, the outback, the coast, towns, race, development and federal government policy. We see how they stay the same. How they recur. How they mutate. How they recur in different forms.

To be sure: this book is a study of Territory writing. But it is also a study of ideas: how they are born, live, change, die and, sometimes, are reincarnated. It is a study of a place so rich as to spark many different and often competing images and stories. This cultural history is also a study of the interaction between place and stories. About how stories and ideas about place and environment can influence our experience of places and how, in turn, this moulds our ideas and stories about both the places and our experience of them. We learn all of this while encountering men who trade in human skeletons; immense spaces, close, lush forests, the sense of freedom and the vertigo that comes with them; the warmth of human camaraderie; bloodcurdling brutality, murder, genocide; the prickly itching of teeming, swarming insects; callous exploitation; literary fraud; uneasy consciences awakening to injustice; unquenchable spiritual longing, unrestrained greedy fantasy and the nihilism of vanquished idealism. All distilled with alacrity and told through judicious quoting that lets us hear so many voices that otherwise had been consigned to oblivion.

Never-Never also reveals profound silences. Aboriginal people do not speak till near the end. In NT writing they are overwhelmingly spoken for, about, over - and almost always to their detriment. Aboriginal people are dehumanised and defined by people whose interests conflict with theirs. Mickey Dewar states in the introduction that despite the vast number and array of voices in NT writing, these voices served the purpose of legitimising the colonising of Australia. They also attempted to define the non-Aboriginal occupation of Australia. ${ }^{10}$ The rest of Never-Never shows this. Laying bare such grievous injustice, this cultural history sheds much light on the present both in the NT and in Australia.

Although Chinese people have lived in the NT since the 1870s, they are also largely absent from this literature. Where they appear, they are also spoken for and about, usually in stereotypes. As a study of predominantly white literature, Never-Never goes a long way to explaining why we think about the NT as we do and how this has come about. 
For the rest of this essay, I will concentrate on three elements of NeverNever that give it enormous value. The first concerns sources - voices if you will - and the strenuous labours Mickey Dewar brought to finding, reading, re-reading, interrogating and interpreting them. These efforts are exemplary. They are a stimulus to reflect on the place of reading in the work of the historian. The second concerns the life cycle(s) of key ideas and images. The third concentrates on ideas of landscape, wilderness and place relating to the NT. In particular, how these elements relate to other dominant ideas of land and wilderness in western culture, and the manner in which they reveal attitudes specific to the NT. We also see that Never-Never is a work that converses with other books from other places that discuss land and place, thereby illustrating ideas of the remote that transcend Australia's shores. A vastly different north to the frigid norths of the northern hemisphere, the NT is nonetheless seen in similar ways.

\section{Reading and reviving forgotten voices}

First appearances can be very deceptive. Never-Never's slender bulk belies the sprawling range and profound depth of its content. Its slim proportions (151 pages excluding notes) obscure the exhaustive labours of locating, reading, thinking about, writing, re-reading, thinking again, writing, interpreting, revising, re-reading, reinterpreting, writing $\ldots$ that went into its creation. Converted from a $\mathrm{PhD}$ thesis, it is relatively brief because the thinking is clear and the prose is uncluttered. But one of its distinctions is the volume and range of its source material.

Casually, the author mentions that she read 'a thousand or so novels and reference books' in her investigations. ${ }^{11}$ This alone is impressive enough. It is also worth noting that this research was undertaken long before relevant public internet content became accessible and the digitising of library collections took place. Mickey Dewar found voices that had long been forgotten. Not only had they faded from memory in broader Australian culture; most had scarcely left a trace that they had once existed. Moreover, many were long forgotten even in the NT. It is worth noting that decades of postmodern sensibility have not completely dislodged centre/periphery notions in Australian cultural life. As Regina Ganter explained, Australian history has long and commonly been constructed as

11 Dewar, In Search of the Never-Never, ix. 
a narrative starting at Sydney Cove and emanating outwards. ${ }^{12}$ Of course, Australian historiography increasingly comprises narratives informed by better fitting structures of space and time. But the NT remains peripheral in Australian history and Australian cultural life. That so many of these works have slipped from cultural memory in the NT speaks to the extent of the forgetting. It also signifies the importance of Never-Never's enormous act of retrieval and revival.

To get a sense of this it is worth looking at the notes and bibliography. Names such as Jeannie Gunn, Xavier Herbert, Bill Harney and Ted Eagan will register with many. Some would know of explorers such as P.P. King and Ludwig Leichhardt. People with a more geographical bent would probably know the works of A.G. Price and W. Howchin. What about A. McDonald's The Lost Explorers from 1906? Or W.B. Wildey's Australasia and the Oceanic Region (1876)? W.C. Willshire's Land of the Dawning (1896)? G. Cossins's The Wings of Silence (1899)? K. Dahl's In Savage Australia (1927)? W. Hatfield's Buffalo Jim (1938)? What about more recent works such as C. Wood's Dead Centre (1980) or I. Moffitt's Death Adder Dreaming (1988)? At a time when information engulfs us and the glut of text accelerates, forgetting is almost ineluctable. Acts of retrieval become especially important. Here the manner is praiseworthy too. Mickey Dewar liberally quotes many of the sources she analyses. We hear the rhythm, metre and cadence of individual voices and the rhythm, metre and cadence of other times.

Reading is the historian's core business. Mickey Dewar's efforts here are worth dwelling on as a reflection of the historian's practice. Historians study and interpret documents, whether written, spoken, illustrated or performed. Through them we encounter the past in its rich alterity. Having confirmed the authenticity of these documents, we examine what they say and how they say it. Language conceals as well as reveals. So we must try to interpret the lacunae as well as the light. We try to account for both deliberate and unintended refraction in the text. Endeavour to identify and interrogate ambiguities. Walter Benjamin referred to it as reading against the grain. The reward: deeper meanings and hidden purposes come to light. In his systematic study of historical thinking, Sam Wineburg identifies three levels at which historians engage with texts. First is the literal text, the meaning and logic of the words. Second,

12 Ganter, 'Turning the Map Upside Down', 26-35. 
the inferred text, what can be logically drawn from the words but is not explicitly stated. Subtext is the third and it distinguishes how historians read from the way other people read. It is the text of 'hidden and latent meanings'. ${ }^{13}$ Two aspects of the text can be read from the subtext. There are rhetorical artefacts from which historians reconstruct the author's purposes and intentions. What Wineburg calls human artefacts are visible in the way a work or document is framed and this discloses the author's assumptions, world-views and fundamental beliefs. Reading to see human artefacts, historians can grasp what authors try to conceal and glimpse their deeper motivations. ${ }^{14}$ Such layered reading enables historians to not only say what a document says but also what it does. Reading Never-Never you will see that Mickey Dewar was adroit at this. However, it is only when we consider the range of source material that she engages with here that we get a real sense of her accomplishment as a reader.

Sources here don't merely divide into fiction and non-fiction. The fiction includes literature, middle- and low-brow novels, adventure stories, childrens' books, fantasy, historical fiction and poetry. Among the non-fiction are serious anthropological and geographical studies, travel journals, biographies, often aggrandising and self-exculpating autobiographies and all manner of government studies. In the $1960 \mathrm{~s}$ and 1970s, J.H. Hexter, Jacques Derrida and Hayden White showed us that fiction and non-fiction, while distinct, are not completely separate. Non-fiction, including history, contains fictive elements. To fragment form and content is to eviscerate a work. It often undermines understanding of ideas, images and arguments. As a cultural history resource, a novel cannot just be read for what its words state about a time or a place. Events in a novel may have deeper meanings that can only be discerned in relation to other events, or recurring images; the course of a narrative often signifies ideas about history or a place. Characters and their development usually stand for important ideas. Sometimes they don't and the reader must understand this too. Recently in Slow Reading in a Hurried Age, literature scholar and critic David Mikics identified a dozen or so tasks necessary to reading fiction. These include: 'be patient', or don't rush to meaning. 'Ask the right questions', questions that connect elements of the book together, is next. Then, 'identify the voice', who speaks and how? Do they speak to each other? Do voices compete or complement each other? Then

13 Wineburg, Historical Thinking and Other Unnatural Acts, 65.

14 For a detailed discussion, Wineburg, Historical Thinking and Other Unnatural Acts, 64-67. 
'get a sense of style', and 'notice beginnings and endings'. Another two are closely related: 'identify signposts' (key images, words, sentences and passages) and 'track key words'. Another, 'find the author's basic thought', is what historians try to do with any document. 'Find the parts' is more explicitly literary, in focusing on structure and turning points. ${ }^{15}$ James Wood's How Fiction Works also emphasises form and structure. Not only the form and structure of a work as a whole, but the form and structure of character's voices - what do they reveal about the character? How do they relate to the work as a whole? What effects does this create? To what end? To understand a work of fiction as a document of cultural history, historians must master all of this. Along with text and subtext we must be able to read form; at the level of narrative, the plot, the sentence, the word. And these must be understood in terms of the conventions and practices of each form and each genre. Characters are more important in novels than in short stories, where theme matters more. In poetry, meaning is found in imagery, connotation, tone, mood, pace, texture and ambiguity, as well as in rhyme and metre. Literature scholar Terry Eagleton even maintains that syntax and punctuation are means to meaning. There is a politics of form and form is a mode of access, even to history. ${ }^{16}$ Documents born of fiction are both rich and difficult for the historian. To be able to read well, across the range of forms and varieties of genres through which the sources of Never-Never speak to us, is laudable.

Examples abound in Never-Never where sources are read for more than content. Content is placed in historical context but is analysed in terms of literary constructs of forms. Throughout, we encounter discussions of stories and characters in relation to heroic models or, say, Arcadian models. ${ }^{17}$ Or references to literary constructions that emphasise, for example, the role of women as 'idealised homemakers. ${ }^{18}$ Reflecting on Harriet Daly's and Jeannie Gunn's autobiographical fiction from the late nineteenth and early twentieth centuries, Dewar notices that the various male characters in the bush are not fully rounded and lack human complexity. Instead, they are caricatures who create a bifurcated image of bushmen: gentle/kind or antisocial; teetotaller or alcoholic. ${ }^{19}$ In time, the more benign images came to dominate. Rather than freshly drawn

15 Mikics, Slow Reading in a Hurried Age, 55-156.

16 Eagleton, How to Read a Poem, 8.

17 Dewar, In Search of the Never-Never, 6.

18 Dewar, In Search of the Never-Never, 141.

19 Dewar, In Search of the Never-Never, 21. 
characters, they are composites of stock images, largely drawn from Henry Lawson. Instead of epitomising and working through more universal human dramas, they paint a picture of the outback as wild but in parts tamed; remote but ultimately benevolent. Their role is to help create a place - the 'Never-Never'.

'Never-Never' is how both the outback and often the Territory - there's usually a lot of slippage here - have been imagined. Implying a place 'out of time', this concept immediately places the Territory as an OTHER, a different place to the rest of Australia. This idea is arresting in its strangeness. On interrogation it is as incoherent as it is strange. How could a physical place be out of time? How could a physical place never be, ever? But, it is a wonderfully evocative, if distancing, name. Reading character, plot, location, absences, silences and form in Jeannie Gunn's We of the Never-Never, Mickey Dewar identifies a literary construct at the core of our idea of the Northern Territory. The idea of the 'Never-Never' then does not issue from common, unmediated experience or even from systematic, empirical examination. It comes from a literary construct that accepts the hardships of the land and has supplied the significant icons and myths that the NT in turn has drawn upon to describe itself and distinguish itself from the rest of Australia, from around 1910 onwards. ${ }^{20}$ Perhaps the vividness of this concept is a clue to its discursive origins and fictive nature. But it was a reading of Jeannie Gunn's opus, attentive to form and literary conventions, which discerned the literary construction that is the 'Never-Never'. A study of NT literature, In Search of the NeverNever is largely an enquiry into the dominant idea about the NT and its echoes. The title, In Search of the Never-Never, tells us exactly what the book is about, the author's central thought if you will.

James Bradley has urged that fiction not be valued for its non-fiction. Even as a work of history, Never-Never values fiction as fiction. We see this in a brief discussion of the literary merits of Capricornia and Buffalo Jim. Reflecting on Xavier Herbert's and William Hatfield's political commitment to justice and representation for Aboriginal people (in both life and literature), Dewar explicitly judges that 'their novels suffer from the soap-box style of their protagonists'. ${ }^{21}$ But stories and literary construction are also examined in terms of their veracity, as adduced by historical evidence. For example, an interrogation of Hugh Atkinson's

20 Dewar, In Search of the Never-Never, 38.

21 Dewar, In Search of the Never-Never, 65. 
historical novel The Longest Wire reveals that writers generally believed that Europeans committed genocide in the 1870s, when the Overland Telegraph was built. This novel specifically includes scenes where the men building the line engaged in racial violence and rape. Yet, as Dewar says, despite the undoubted allegorical and general truth about colonial/invader violence and even genocide, there is no historical evidence to support the specifics of Atkinson's portrayal. ${ }^{22}$ Indeed, this represents an inversion of what Mickey Dewar terms the construction of the relationship of Europeans to Aborigines. Earliest accounts refused to acknowledge violence against Aboriginal people, even when overwhelming historical evidence corroborated these atrocities. By the 1980s and '90s, however, writers assumed this violence even where historical evidence tells us otherwise.

Before the insights of the linguistic turn came to influence history in Australia, prominent historians saw the worth of fiction for history. Manning Clark speaks of his voluminous and laborious reading that helped him conceive of how to tell 'the story' in his History of Australia series. Authors he attentively read and re-read in preparing to both write and research this work include Job, Luke, Aristotle, Dostoyevsky, Tolstoy, Nietzsche, Hardy, Shakespeare, Dickens, Melville, Henry Lawson, Thomas Carlyle and Edward Gibbon. ${ }^{23}$ Declaring that without imagination there can be no history, Keith Hancock insisted that historians must be good readers, not just of non-fiction but also of novels and drama. ${ }^{24}$ History, according to Hancock, must combine span and precision and, to do this, historians need also to become playwrights, poets, painters, musicians, novelists... Even at a time when the opacity of the word was perhaps not as well understood as it is now, distinguished historians did grasp the need to understand how narrative and various kinds of literary form are made. The Herculean reading at the foundation of In Search of the NeverNever evinces this understanding. It embodies Ranke's exhaustive study of documents, with perhaps more of an emphasis on symbols and semiotics than on philology, Hancock's span, Clarke's concern for form, character and story and post-structural insights about emplotment, language and power. What stories, then, does it tell us about the NT?

22 Dewar, In Search of the Never-Never, 179.

23 Clark, A Historian's Apprenticeship, 21-31.

24 Hancock, Professing History, 20-21. 


\section{Stories about stories about 'The Territory'}

A core of vital themes emerges from the ocean of words written about the NT. The original word worlds were crafted by people who resided in or visited the NT. For some, home was elsewhere and ideas of home were ideas of other places. Others tried to make a new home through their words. Never-Never orders this discourse into clear ideas. Its chapters, arranged both thematically and chronologically, carve out particular periods and ideas that I will now outline. Chapters 1 and 2 deal with the early post-invasion period: circa 1870 to the First World War. Chapter 1, 'Writing the Landscape', tells of early newcomer preoccupation with landscape, flora and fauna. Driven by cultural needs for both distinctive subject matter and style, this manifested in contradictory ideas about the land. Before 1910 or thereabouts land was depicted as enemy or as holding great economic potential - yes, the latter is a very old idea, as yet unrealised. Later in this period, land was also depicted within Arcadian models. Chapter 2, 'The People', examines how people were drawn in the writing of the time. Most images, whether about Aboriginal or nonAboriginal people, were recognisable caricatures. Depictions of Aboriginal people conveyed a pervasive, relentless and brutal racism. Renderings of non-Aboriginal men gave birth to archetypes of outback bushmen that endure in two ideas.: one, in the outback, mateship transcends usual class barriers; and two, that men seek solace in the bush after a broken romance.

'Looking for Gold', Chapter 3, takes us to after the First World War. At this time, Territory writing emphasises the culture of the frontier. This is the genesis of ideas still associated with the NT: a place of adventure, violence; wilfully unruly, casual, excessive. But the title points to another strong strand: pursuit of mineral and industrial wealth. Yet, as the bush lifestyle was celebrated, others advocated its displacement through industry. This was animated by the potent twentieth-century myth: that of fabulous mineral wealth under the rocks of the NT.

Chapter 4, 'Race Relations', is an unflinching look at racist depictions of Aboriginal peoples in the period leading up to the Second World War. Preoccupied with essentialist notions of race and concerns about 'mixing and degeneration', we see that much literature of the period propagates such dominant scientific ideas. However, Xavier Herbert debunked these ideas in Capricornia. Then there are the stories about white women rendered decadent in the tropical north. 
In Chapter 5, 'The Atomic Territory', we are in the postwar period. When, as uranium was discovered in the NT, outback iconography becomes prominent. No longer a place for adventure, the Territory is now made as a place for inspiration drawn from its unique landscapes. Yet, at the same time, the urge to develop becomes part of a broader narrative about science and progress.

Covering the same period, 'Sex and the Dreamtime' (Chapter 6) shows that other writers constructed a different Territory of the 1950s and 1960s. They depicted a place populated with sexual tensions, with particular concern for exploitative relationships between European men and Aboriginal women. For the first time, non-Aboriginal people came to be seen, explicitly, as outsiders to the Territory. Here the land became dangerous and hostile again to who trespassed.

The recasting of the NT landscape in the 1970s to a role more familiar to us now is the subject of Chapter 7. 'Welcome to Wilderness' places this change in the context of broader movements of environmentalism, pluralism and feminism. The NT came to be deliberately defined in relation to the rest of Australia. It was the one place to access wilderness and the spiritual renewal it affords, as well as to witness the people who have long lived harmoniously with this environment. Wilderness was no longer the frontier. The frontier and its ordeals of initiation were where the visitor encountered non-urban Territorians; the final barrier to accessing wilderness.

Finally, in a nod to Xavier Herbert, 'Poor Bugger All of Us', examines how literature portrays Territorians relating to each other and to the landscape. The period is the 1980s and '90s. Aboriginal people are largely depicted as spiritual beings. Gender manifests in distinctions between Aboriginal women and European women. The former are drawn as strong and intelligent; the latter as superficial and even bitter. More broadly, Europeans are identified as environmental destroyers; Aborigines as conservers.

I have gone into such detail to give a sense of just how many ways the NT and aspects of its life and people have been imagined by writers over time. This by no means exhausts the stock. What Mickey Dewar called the literary model of the Northern Territory has undergone yet more transformations. In this history, as she presents it, we see many continuities too. But this model is worth understanding because it informs how so 
many people who have not personally experienced the NT understand it and its history. I suspect these stories help residents better apprehend life in the NT and other stories about the Territory too. Geographer Edward Relph notes that the identity of a place features three interrelated components: physical features and appearance, functions and activities, and meanings/symbols. ${ }^{25}$ Meanings come from stories and beliefs about places and kinds of places. More fundamentally, environmental scientist and literature scholar George Seddon observed that how we perceive, imagine, conceptualise and relate to the physical world is partly a result of cultural conditioning. ${ }^{26}$ Stories, including histories, shape our sense of place. They supply ideas and images, which help us form beliefs that then inform our subsequent perception of place, experientially and in text. Conceptually, it is easy to see that certain ideas of place can gain currency without a substantial basis in reality. Other images can undermine this. Never-Never identifies vivid yet conflicting and even duelling images about the NT in its writing.

What do these stories about stories about the NT tell us?

We learn that this land of the imagination was a place where many ideas coexisted. This happened within certain periods; it happened across periods. In each period, ideas contradicted or were in direct contest with each other. Notions and ideas of land, race, development, wilderness and gender inform the literary model throughout the period but were refracted through particular ideas, images and motifs. These mutated frequently. This happened in response to larger social and political movements sometimes in reaction to earlier ideas or concurrent concepts. Many of these ideas have long lives or multiple reincarnations. By tracing the major themes of Aboriginal people, gender, development and ideas of land/ wilderness, we get an even better sense of all of this.

\section{Tracing themes}

Most depictions of Aboriginal people in the corpus of NT writing are offensive. Yet, confronting them is necessary and instructive. Coming to know these images, we gain a good sense of the key problems inherent in relationships been Aboriginal and non-Aboriginal peoples in Australia -

25 Relph, Place and Placelessness, 61.

26 Seddon, Landprints, 13. 
now and in the past. On a broader point of cultural history, they also show that ideas do not have to be good, nor do they even need to reflect reality in order to live a long life. Ideas don't need to make sense. They only need to have a use or to fill a void. Images of Aboriginal people were by no means uniform but they were denigrating. Mickey Dewar shows us that in NT literature before 1905, there is no example of anything as humane as friendship between Europeans and Aborigines. Aboriginal people are generally depicted as aggressive and threatening or, in late nineteenthcentury fantasy writing, as a degraded form of a once 'higher, ancient civilisation' ${ }^{27}$ At the same time, Aborigines in the outback were portrayed in more favourable terms than those in the towns. In the 1920s and 1930s, the depictions have a strongly ethnographic and anthropological flavour, being particularly preoccupied by biological notions of race and miscegenation. Aborigines were understood as a doomed people. Aboriginality was graded in fractions of race, calibrated by flawed understandings of genetic descent and its meaning.

In adventure stories, Aboriginal people were still depicted as menacing. In other genres such as journalism, biography and fiction more broadly, Aboriginal people were defined by biology and racialised in a manner that justified white attitudes of racial and cultural superiority. Amid this, mythologies of cannibalism emerged in both fiction and non-fiction. Yet, during the same period, the idea of Aborigines with occult powers, especially telepathy and in relation to land and nature, also emerged. Following the Second World War and the discrediting of race-based thinking and eugenics, the idea of the doomed Aborigine lost credence. Images of Aborigines accorded with white political and cultural aspirations for assimilation. It is worth stressing here that these images were not the product of a remote and isolated culture: they reflected dominant scientific and political consensus. NT writing tapped into both national and global thinking.

The image of the telepathic Aborigine has recurred since this time. The 1950s saw a new interest in both Aboriginal mythology and in sexual relations between white men and Aboriginal women. Never-Never also shows us that on this the writing is ambivalent - focusing on either the exploitative nature of these relationships or on the widespread acceptance of them. The 1970s saw the emergence of Aboriginal people as spiritual 
beings in NT writing, especially in relation to wilderness or the outback. While far more humane than other manifold derogatory stereotypes, this is still something of a mutation of older ideas of Aborigines and telepathy. It is also a white projection on Aboriginal people, not an expression of Aboriginal voices. Moreover, after being burdened with being represented as degraded and inferior, and as obstacles to progress and development, Aboriginal people were then burdened with providing a homegrown spirituality for Australia's existentially lost souls. We see a similar dynamic in portrayals of Aboriginal characters in 1980s and '90s Territory writing - as protectors and preservers of the environment in contrast to European destroyers. The content has changed and, thankfully, it is more humane and positive. But even in the 1990s, Aboriginal people were still being defined and spoken for, and they were still being cast instrumentally in relation to the needs of non-Aboriginal people.

Some writing did dissent from this. But Never-Never shows that this represents a small proportion of the overall mass of text. Xavier Herbert's Capricornia (1938) is the most outstanding example. Two pages of Never-Never discuss how characters in Capricornia debunk the notion of Aborigines as cannibals, the rectitude of forced child removals and any sense that government administration did actually work for the benefit of Aborigines. ${ }^{28}$ Herbert was not alone. Other writers such as William Hatfield and Bill Harney demonstrated similar thinking in their writing. In Desert Saga (1933) Hatfield even tried to present the narrative from an Aboriginal perspective. But, as Mickey Dewar discerned in her readings, the protagonist's thinking was biblical rather than Aboriginal. ${ }^{29}$ In other words, despite the structure of the narrative, this character was not thinking and acting from an Aboriginal perspective at all. Overwhelmingly, then, for its multitude of voices, variety of images and characterisations and plethora of ideas, this was not a literature that challenged prevailing ideas of race or government policies in relation to Aborigines. On these matters it was startlingly conformist, supporting the argument of Never-Never that NT literature served to legitimise European occupation of Australia.

Literary images relating to gender were both remarkably fluid and remarkably resilient. Through the course of Never-Never, we see striking differences between the portrayal of Aboriginal women and white women. Aboriginal women tended to be invisible in the earliest literature. 
Aboriginal men are present, represented as a general and pervasive threat to the European project of developing and 'civilising' the north. As Dewar shows, this is an image that recurs for many decades. When Aboriginal women do appear in the early twentieth century, they are in white domestic space and are depicted as good workers. From about the 1930s, portrayals of sexual relations between white men and Aboriginal women feature openly. With some depicting exploitation, it seems reasonable to read sexual exploitation of Aboriginal women into earlier stories portraying domestic service. In much NT writing post 1960, Aboriginal women (and men) are guardians of the land, skilled and knowledgeable about the environment. Never-Never identifies a remarkable contrast in the depiction of Aboriginal women compared to white women in the more recent literature it studies. While Aboriginal women are presented as strong and loyal, white women are often victims of violence, depicted with little or no sympathy; or portrayed as shrill 'femmocrats'. ${ }^{30}$ And not only by male authors. Referring to a passage discussing relations between white and Aboriginal women in Herbert's Poor Fellow My Country (1975), Mickey Dewar explains this hostility. White women were seen to be a crimp on white bushmen's sexual licentiousness. They had been represented in this manner in earlier writing too. ${ }^{31}$ This idea of white women as social guardians was a strong and recurrent one in NT literature. It features in the writing of Jeannie Gunn at the turn of the century. It is resurrected in the 1950s, Dewar argues, to support strong cultural and political aspirations for social stability, bolstered by an idealised notion of the nuclear family. Another and very different idea of white women in the NT was also constructed. This was the 'plucky', strong, feisty, independent woman. She appeared in the early twentieth century, usually on a pastoral station. In later depictions, she was usually of the outback rather than the town or city.

Constructions of white men, however, have been more politically potent. In early times they were the brave, noble, loyal yet independent and rule-breaking bushmen. Although idealised, they were not presented as perfect but sometimes as drinking and brawling. In later times, white men are often characterised as destroyers: some are defeated, nihilistic and self-destructive, while others are complacent, uncaring, prosperous and tenaciously narrow-minded. Of these images, it is that of the bushman 
that has proven the most enduring and politically powerful. It is hard not to notice the likeness between the image of the NT bushmen and the caricatures at the heart of Russell Ward's Australian Legend. In the 1950s, Ward, among other radical nationalist thinkers, reflected on Australian culture in the period leading to the birth of the Australian nation. The bushman was not simply a local character in the pastoral north, but emerged as emblematic of a distinctive ethos of egalitarianism, independence and anti-authoritarianism that has long been used to further political and cultural agendas. To an extent, the bushman became a sacred cow in Australian cultural and political life. Anthropologist Tess Lea has recently highlighted the serious consequences of this in the Territory. The image of the largely benevolent bushman has been acquired by pastoralism in general. The endurance of this benign iconography, Lea argues, has kept many local historians in the NT from engaging critically with stories - even propaganda - circulated with the intention of casting industries such as pastoralism and mining in a favourable light. ${ }^{32}$ Lea relates that in the early twentieth century, cattle empires Bovril's and the Union Cold Storage Company (Vestey's) exploited labour, suppressed wages, avoided tax, degraded the land and drove traditional owners off their own land..$^{33}$ Few know of this today: the icons of the bushman and the stockman have created many erasures and occluded knowledge of exploitation of both Aborigines and (their) land. Anthropologist Deborah Bird Rose contends that this is not so unusual. Indeed, forgetting is an inherent aspect of industrialisation and even modernity, especially in nonurban places targeted for development and for a long time regarded as terra nullius. ${ }^{34}$ So, the true nature of pastoralism, at least in earlier times, remains unknown to most Australians and even most residents of the NT to this day. Unmasking icons and motif-ridden stories is vital. There is no reason to believe that various industries do not exploit the very same play between iconography and forgetting today.

If current plans to develop Australia's north seem stale, Never-Never helps explain why. Historian Libby Robin gives a thorough history and explanation of how previous grand plans for northern development have failed in How a Continent Created a Nation (2007). The schemes were too crude, imposing an environmental homogeneity upon the north and so paid little or no attention to local ecological realities. And they forgot earlier

32 Lea, Darwin, 55-62.

33 Lea, Darwin, 55-62.

34 Rose, Reports from a Wild Country, 53-72. 
failures. ${ }^{35}$ Agricultural economist Bruce Davidson identified physical and economical constraints on the project of northern development in The Northern Myth back in 1965. Yet In Search of the Never-Never reminds us that the idea of the Northern Territory as a source of boundless abundance and wealth dates back to the first half of the nineteenth century. So, it predates the establishment of a permanent colony at Darwin and came in two forms. There was biographical journalism that asserted the economic potential of the region. There were also fantasy stories featuring heroes who travelled to the centre of Australia in search of gold. Until about 1910, numerous novels appeared, serving to instil the idea that central and northern Australia were lands of 'fantastic possibility'. ${ }^{36}$ Fears of a northern invasion strengthened their power, bolstering the development imperative of the late nineteenth century. Japan's victory in the Russo-Japanese War in 1905 invigorated these sentiments. But the idea that underneath the rocks of the NT lay exceptional mineral wealth became, between the two world wars, the most dominant and consuming myth in NT writing. Never-Never cities a large number of works that propagate this idea. ${ }^{37}$ The later discovery of uranium gave this idea even more potency in Territory literature. Though we also learn that critics had emerged by then, with heightened environmental awareness from the 1970s onwards, qualifying these ideas. Yet the development imperative still dominates politics in and relating to north Australia today. Its durability can to a large extent be accounted for by persistent profit seeking. But, with the endurance of these ideas in NT writing, they have also established deep cultural roots. It is hard not to think that the persistence of the idea that the NT has vast reserves of untapped mineral wealth and limitless potential for economic development enables the repeated proposing of schemes that in other places might more readily be recognised as unviable.

Land, wilderness and place are the last major theme. In discussing NeverNever's treatment of these, we see that the NT has had very distinctive ideas of wilderness in particular. It will also become clear that Never-Never reveals important and as yet unrecognised similarities between the NT and other 'norths' around the world. In examining stories about land and wilderness, In Search of the Never-Never also stands as a cultural history that does some important environmental history. 


\section{The peopled wilderness}

In Territory writing, depictions of land yield vivid images. Yet ideas of land and landscape have long been fluid and riven with contradiction. Early on, land was hostile, dangerous, to be subdued. In this very danger, in the power of its threat, it was seen to be imbued with spiritual powers. At the same time, it housed great bounties. The process of exploiting these would not only provide wealth but also quell the land's dangerous forces. Soon after, it was also conceived as Arcadian: harmonious and sustaining. In its hostile guise, it was a testing ground for character and heroism. Later it became a theatre of adventure and for authenticating masculinity. The land has been seen as empty and also as populated. In the 1950 s and '60s it came to be depicted as part of outback iconography and re-imagined as a place not of adventure but of inspiration. More recently, it has been seen as a place of renewal, filled with spirituality, with the Indigenous people who have lived on it for millennia imagined as part of it. Here it is seen by white Australian writers as a place to engage in spiritual replenishment, through contact with the land and its long-term owners and custodians. At the same time, some literature has imagined the land as hostile to those non-Indigenous people who don't 'belong': the hostile landscape has returned in a different form.

Ecologically, the NT is particularly diverse. It has locales that are always rainforest, others that are always desert. It features islands, grasslands, scrub and dry forests and much of the Territory transforms into various kinds of desert for a variable six- to eight-month period each year. NeverNever convincingly illustrates patterns that show how the influence of culture has been at least as strong in NT writing as the influence of nature.

Contradictory attitudes to nature have a long history in western letters. Kinds of environment and particular places also elicit contending attitudes and images. In Wilderness and the American Mind, United States cultural and environmental historian Roderick Nash shows that wilderness has been conceived as different kinds of environment, usually desert or 'untamed' forest. Using biblical texts, he also reveals that even when imagined as a particular kind of environment, say, desert, wilderness has been imbued with different and usually contradictory characteristics and values. This is to say that the same environment has long represented disparate things. The term 'wilderness' is used 245 times in the Old Testament and is mostly equated with desolation or wasteland. In numerous biblical 
stories, 'wilderness' is also explicitly desert. Its key contrast is with the Garden of Eden and the tamed cultivation that it symbolises. In early Judeo-Christian thinking, wilderness isn't amoral, but from Hebraic folk tales, it inherited a sense of being populated with malevolent and immoral forces. ${ }^{38}$ The idea of a hostile, forbidding land gains enormous currency in the Old Testament and we see in Never-Never that it resonated with early writers about the NT. But other ideas of wilderness come with the totemic biblical story of the Israelites wandering in the desert for 40 years. Here wilderness appears as a place of sanctuary, purity, a spiritual place to come closer to god and as testing ground. Variously defined in NT writing as the outback or the lands beyond town limits that hadn't been converted to pastoralism, wilderness in NT writing also reverberated with these ideas of spiritual encounter, sanctuary and testing ground. This contradiction, this duality, persists through the whole period that Never-Never takes into account. Wilderness has long been a cultural place even more than a physical place.

NT writing has transposed the culture of other places and times onto the NT landscape and environment. However, in this literature, older ideas acquire a new flavour. Biblical notions of wilderness refer to desolate places devoid of humans. Notwithstanding the erroneous and now discredited legal fiction of terra nullius, people lived in the NT wilderness and had for a period that registers on the scale of deep time: about 60,000 years. Very early writings mostly depicted the NT as a wilderness to be subdued: empty and hostile. ${ }^{39}$ But in W.C. Willshire's Land of the Dawning (1896) Aboriginal people come to be represented as yet another danger in this wilderness. After this, as Mickey Dewar shows, adventure stories construct Aboriginal people as a threat to Europeans that defines this dangerous environment. ${ }^{40}$ Dewar also reveals that such depictions of Aboriginal people are a stock image copied from depictions of Aborigines in the journals of Matthew Flinders, Ludwig Leichhardt and David Lindsay. Only much later are Aboriginal people depicted as the land's protectors. As we have seen, Never-Never explains that in NT writing, the Territory wilderness is inhabited by people who appear in various guises: the telepathic Aborigine, the wise custodian, the keeper of Indigenous knowledge and, in the late twentieth century, mostly as a spiritual being deeply connected to the spiritual bounty of the wilderness. So whereas

38 See Nash, Wilderness and the American Mind, 13-17.

39 Dewar, In Search of the Never-Never, 2-4.

40 Dewar, In Search of the Never-Never, 23. 
early on, Aboriginal people were depicted as part of the wild's menace, later they are represented as integral to the NT wilderness as a place for renewal, restoration and inspiration. Just as some white Australian writers came to project profound existential demands on to Aboriginal people, so too have they done the same in relation their lands.

Never-Never unveils a very distinctive incarnation of the wilderness idea. Even today, wilderness is predominantly understood as a place without people. Inherent in conservation battles in North America and southern Australia was the idea that wilderness is either untouched or lightly touched by humans and largely devoid of man-made structures and permanent human habitation. This is the conceptual basis of laws relating to wilderness. Influenced by the Bible, Henry David Thoreau, John Muir, Aldo Leopold, and others, this is an enduring and influential idea in western thinking. The Franklin Wilderness of Tasmania was depicted as a pristine environment and this conceptual framing helped animate the successful battle to save it. But Never-Never illustrates that NT literature - at the same time and afterwards - depicted a wilderness in which Aboriginal people lived in harmony with nature. ${ }^{41}$ We should again note that much of this literature was written by people who came from or who lived in other parts of Australia. Accordingly, many would have held these different ideas of wilderness simultaneously. Portrayed as spiritual guardians of the land and its enigmatic truths, Aboriginal people, however, had become inseparable from the constructs of land and wilderness drawn by NT writing. Crucially, this was a peopled wilderness.

The idea of the wilderness as a place of trial has also endured. However, the nature of the trial has changed. In late twentieth-century writing about the NT, before the outsider gets to the character-building, selfrevealing wilds, they must endure the trial of contact with the townsfolk who live on the frontier between the rest of Australia and the wilderness. ${ }^{42}$ The land itself ceased to be the testing ground; accessing it had become the trial. This was just the latest idea of trial in the NT landscape. First, it was to overcome the hostile wilds to impose order and extract wealth. After the First World War it was a trial in terms of adventure, courage and individual strength and endurance, and these two incompatible notions were in direct conflict with each other. Then the land was seen as suffused with spiritually nourishing qualities. This idea conflicted with plans,

41 Dewar, In Search of the Never-Never, 150-53.

42 Dewar, In Search of the Never-Never, 151. 
aspirations and narratives of development, geared at securing wealth and guiding 'progress': a tamed wilderness no longer offers spiritual sustenance. Over time, the development/conservation battles in the NT have been animated by vastly different values and aspirations. Wilderness has meant many things to different people, but it is not the only literary construction developed for imagining land and place in NT writing.

Circa 1900, the far north was depicted as Arcadian. Arcadian models of nature come from Roman literature, particularly works such as Virgil's Georgics and Eclogues. The Arcadian ideal is of land and nature that are tamed, harmonious and fruitful. It is a coloniser's idyll. In Never-Never we see that writers such as Harriet Daly use it in a manner that depicts the far north of the NT as having been subdued and as no longer wild. ${ }^{43}$ At the time, some may have read this to suggest that in time the same would happen throughout the rest of the NT. But was it ever wild, except in the invader imagination? Using accounts of George Goyder and his team as they set about establishing the colony at Darwin in 1869, historian Bill Gammage indicates otherwise. Although Goyder did not recognise it himself, this was a land tended to by the Larrakia people who had long systematically burned the land in attentive mosaic patterns that varied depending on local ecological conditions. ${ }^{44}$ This was not wilderness, but managed land. Indeed, as Gammage, as well as others including Rhys Jones in the late 1960s, tell us, this has long happened across Australia.

Indeed, for the Aboriginal peoples of the NT, 'wilderness' did not emerge until after invasion and the imposing of colonial land regimes on the Territory. For example, Aboriginal people from the Victoria River district believe that wilderness is man-made and cattle-made. ${ }^{45}$ To quote anthropologist Deborah Bird Rose, a wild place is 'where the life of the country was falling down into the gullies and washing away with the rains ${ }^{\prime}{ }^{46}$ It is worth noting, too, that when Aboriginal voices finally appear in NT writing, they do not discuss landscape and wilderness. Instead their focus is on dispossession, inequality and institutionalised racism; $;{ }^{47}$ root causes of what some Aboriginal people term wilderness.

43 Dewar, In Search of the Never-Never, 6.

44 Gammage, The Biggest Estate on Earth, 271-75.

45 Rose, Reports from a Wild Country, 4.

46 Rose, Reports from a Wild Country, 4.

47 Dewar, In Search of the Never-Never, 182. 
Wilderness is a European import. It is more a product of imagination than of the physical world. It is vivid, is applied to often spectacular and evocative physical environments and has been a worthwhile concept for people who reasonably are trying to curb industrialisation and unrelenting economic exploitation. But, as William Cronon highlights, it is an incoherent idea that can undermine its very goals. The core of the most dominant idea of wilderness in North America (and Australia) sets humans outside of nature and so flees history and its own cultural context. ${ }^{48}$ Establishing this human/non-human dichotomy leads us to misunderstand and undervalue all manner of ecologies that might be worth preserving. It can render people blind to places of value or result in failures to grasp fully what is ecologically and culturally significant in places people already favour for conservation. Moreover, this dualism is morally dubious because it structurally denies that people have lived in places that they had long made their home. In Never-Never we see how the wilderness idea has served various needs in the NT. Writers constructed a distinctive wilderness in the NT, one usually linked to people - the traditional owners and custodians. People are present in this wilderness and in recent times are somewhat idealised. Before this idea emerged, wilderness in the NT was the same as elsewhere in Australia or North America: a place to be conquered, a place in which to test oneself, or a place where a visitor or new arrival might be renewed. The emergence of a new wilderness idea indicates particular cultural and spiritual needs among Australian writers in the late twentieth century for homegrown meaning and spiritual sustenance. With its distinctive landscapes and people, the NT was the one part of Australia onto which these needs and aspirations could be projected.

Re-reading Never-Never now also reveals the NT to be another kind of place: a north. In 1997 when it was first published this was harder to discern. Now, Mickey Dewar's opus can be read in dialogue with books such as Peter Davidson's The Idea of North (2016 [2005]). Davidson canvasses the way northern parts of various northern hemisphere countries are imagined by the larger populations that live in southern parts of Britain, Scandinavia, Canada, Japan and China. He identified that each had a place identified as 'north'. But north here does not designate a mere geographical bearing or physical placing. North is imbued with meaning and symbolism. The north is a kind of place. From manifold works of 
art and literature, Davidson has interpreted the north as a harder place, isolated, a place of dearth, desolation, intractable elements of climate, topography and humanity..$^{49}$ It is also a powerful testing zone; a place of exile, of absence, of failed industries and of a lack of alternatives; and an Other. ${ }^{50}$

Notwithstanding that the dominant motifs of these norths are ice, snow and whiteness, the overlap with the ideas of place in NT literature is remarkable. At first blush this reinforces what we already know about how our understandings of the NT as a place are based on imported ideas and concepts. More reflection on this will reveal even more about how we have understood the NT in word and imagination: not just the content but also how we structure key concepts and the assumptions behind this structure.

\section{New knowing}

A republic of letters we hardly knew existed has shaped how we see a vast, evocative part of this continent. Unveiling this, In Search of the Never-Never has shown not only how that entity has come about, but attests to its enduring force. This work allows us to better understand the Northern Territory and the role it has played in the Australian nation and beyond. This most attentive reading of countless sources, with deliberate regard for form, tone, voice, character, place, content, symbols, imagery, makes for a rich work of history. It is a history of ideas about the NT, and it is a history of constructing a place. It is also a history of ideas in themselves.

Ideas are born, they live, they change, they go dormant, they are born again; occasionally they even die. Ideas are historical; literature and culture are historical. In Search of the Never-Never demonstrates this; it discerns and details these multiple Territory histories. We see that the search for the 'Never-Never' is a search that never arrives at a stable, whole and unified locus called the NT. This is a place of the imagination - the physical place one of multiple, competing, even entangled histories, stories and imaginings.

49 Davidson, The Idea of North, 11.

50 Davidson, The Idea of North, 12-20. 
'The most generous thing a scholar can do is read', Tom Griffiths tells us in The Art of Time Travel. ${ }^{51}$ 'Read thoughtfully, widely and in context', Tom exhorts us. ${ }^{52}$ Mickey Dewar, clearly, has been remarkably generous in labouring to produce In Search of the Never-Never. Read it carefully. Then, read it again. You may come to know the Northern Territory as you have never known it before. You may come to reflect on Australia, even your particular part of it, and come to know both as you never have before.

\section{Bibliography}

Carment, David. Looking at Darwin's Past: Material Evidence of European Settlement in Tropical Australia. Darwin: North Australia Research Unit (NARU), ANU, 1992.

Carment, David. Territorianism: Politics and Identity in Australia's Northern Territory 1978-2001. Melbourne: Australian Scholarly Publishing, 2007.

Clark, Manning. A Historian's Apprenticeship. Melbourne: Melbourne University Press, 1992.

Cronon, William. 'A Place for Stories: Nature, History, Narrative'. Journal of American History 78 (1992): 1375. doi.org/10.2307/2079346.

Cronon, William. 'The Trouble With Wilderness'. In Uncommon Ground, edited by William Cronon, 80-90. New York: W.W. Norton, 1996.

Davidson, Peter. The Idea of North. 2nd ed. London: Reakton, 2016.

Dewar, Mickey. In Search of the Never-Never, Looking for Australia in Northern Territory Writing. Darwin: Northern Territory University Press, 1997.

Eagleton, Terry. How to Read a Poem. Oxford: Blackwell, 2007.

Gammage, Bill. The Biggest Estate on Earth. Sydney: Allen \& Unwin, 2012.

Ganter, Elizabeth. Reluctant Representatives: Blackfella Bureaucrats Speak in Australia's North. Canberra: ANU Press, 2017. doi.org/10.22459/ CAEPR37.11.2016.

51 Griffiths, The Art of Time Travel, 15.

52 Griffiths, The Art of Time Travel, 15. 
Ganter, Regina. 'Turning the Map Upside Down', History Compass 4 (2006): 26-35. doi.org/10.1111/j.1478-0542.2006.00301.x.

Ganter, Regina. Mixed Relations: Asian-Aboriginal Contact in North Australia, with contributions from Julia Martinez and Gary Lee. Crawley: University of Western Australia Press, 2006.

Griffiths, Tom. The Art of Time Travel. Melbourne: Black Inc., 2016.

Hancock, Keith. Professing History. Sydney: Sydney University Press, 1976.

Lea, Tess. Darwin. Sydney: NewSouth Publishing, 2014.

Lewis, Darrell. A Wild History. Melbourne: Monash University Publishing, 2012.

Macknight, Campbell. The Voyage to Marege. Melbourne: Melbourne University Press, 1976.

McGrath, Ann. 'Born in the Cattle': Aborigines in the Cattle Country. Sydney: Allen \& Unwin, 1987 (republished 2012).

Mikics, David. Slow Reading in a Hurried Age. Boston: President and Fellows of Harvard College, 2013.

Nash, Roderick. Wilderness and the American Mind. 4th ed. New Haven: Yale University Press, 2001.

O’Brien, Chris. 'Rethinking Seasons: Changing Climate, Changing Time'. In A Cultural History of Climate Change, edited by Tom Bristow and Thomas H. Ford. Oxford: Routledge, 2016.

Rademaker, Laura. Found in Translation: Many Meanings on a North Australian Mission. Honolulu: University of Hawai'i Press, 2018.

Read, P. and Read, J. eds. Long Time, Olden Time: Aboriginal Accounts of Northern Territory History. Alice Springs: Institute for Aboriginal Development Publications, 1991.

Relph, Edward. Place and Placelessness. London: Pion, 1976.

Reynolds, Henry. North of Capricorn. Sydney: Allen \& Unwin, 2003.

Robin, Libby. How a Continent Created a Nation. Sydney: UNSW Press, 2007.

Rose, Deborah Bird. Reports from a Wild Country: Ethics for Decolonisation. Sydney: UNSW Press, 2004. 
IN SEARCH OF THE NEVER-NEVER

Rowse, Tim. Indigenous and Other Australians since 1901. Sydney: UNSW Press, 2017.

Seddon, George. Landprints: Reflections on Place and Landscape. Cambridge: Cambridge University Press, 1997.

Wineburg, Sam. Historical Thinking and Other Unnatural Acts. Philidelphia: Temple University Press, 2001. 
This text is taken from In Search of the Never-Never: Mickey Dewar: Champion of History Across Many Genres, edited by Ann McGrath, published 2019 by ANU Press, The Australian National University,

Canberra, Australia.

doi.org/10.22459/ISNN.2019.02 